\title{
MENGIKUTI LANGKAH PIKIR ROMO MANGUN Sebuah Tinjauan Mengenai Metode Perancangan Arsitektur Yusuf Bilyarta Mangunwijaya
}

\author{
Rony Gunawan Sunaryo \\ Staf Pengajar Fakultas Teknik Sipil dan Perencanaan, Jurusan Arsitektur, Universitas Kristen Petra, Surabaya. \\ Email: ronygunawan@peter.petra.ac.id
}

\begin{abstract}
ABSTRAK
Dalam wacana arsitektur Indonesia Romo Mangun dikenal sebagai seorang arsitek dan perencana dengan pemikiran yang multiperspektif dikarenakan latar belakang pendidikan dan pengalaman yang multidisiplin. Kekayaan wacana pengetahuan dan pengalaman beliau turut mewarnai artefak arsitektur yang dihasilkan. Perwujudan sebuah artefak arsitektur melalui sebuah rangkaian proses panjang meliputi filosofi, proses kreatif, pelaksanaan hingga komunikasi dengan klien dan pelaksana. Proses ini selalu merupakan topik yang menarik untuk dikupas kembali karena menyingkapkan dua sisi sekaligus, yaitu sisi teknis yang mekanis dan sisi non teknis yang manusiawi.
\end{abstract}

Kata kunci: Romo Mangun, proses perancangan arsitektur.

\section{ABSTRACT}

In Indonesian architecture history, Romo Mangun is known as an architect and planner with multi-perspective of knowledge because of his educational and experience background. His architectural artefact is very much affected by his richness of knowledge and experience. The design process of Romo Mangun's artefact consists of philosophy approach, creative approach, technical approach and communication with client and builder. This process is very valuable to be discussed because it includes two different sides work inline; technical side which is mechanical view and non-technical side which is human view.

Keywords: Romo Mangun, architectural design process.

\section{PENDAHULUAN}

Yusuf Bilyarta Mangunwijaya atau lebih kita kenal dengan Romo Mangun, semasa hidupnya adalah pengajar, budayawan dan praktisi arsitek di Indonesia. Karya-karyanya - yang sebagian besar bangunan religius - tersebar di seluruh penjuru Nusantara. Penghargaan formal maupun pengakuan yang bersifat informal atas Romo Mangun dan karyakaryanya dapat kita telusuri dari banyaknya literatur yang membahas mengenainya. Dari sisi arsitektur, tulisan ini mencoba untuk mengupas bagaimana Romo Mangun memproses sebuah gagasan menuju wujud fisiknya.

Romo Mangun, dilahirkan di Ambarawa, Jawa Tengah pada tahun 1929. Menerima tahbisan imamatnya pada 1959, menjadi imam Pradja Keuskupan Agung Semarang. Dari pendidikannya di Aachen, Jerman beliau menyandang predikat pastor arsitek. Kiprahnya beragam, mulai dari penulis di berbagai media, penulis buku fiksi dan non fiksi, sastrawan, budayawan, rohaniwan, staf pengajar di Jurusan Arsitektur UGM Yogyakarta, mengundurkan diri dari dunia pendidikan 1982, mengundurkan diri dari konsep 'grand architecture' 1988, prinsip beliau tentang arsitektur adalah kewajiban untuk berpihak pada kaum lemah.

\section{FILOSOFI TENTANG ARSITEKTUR}

Pengertian kata Arsitektur yang berangkat dari architectoon (bhs. Yunani) yang berarti tukang ahli bangunan yang utama. Romo Mangun menilai pengertian ini masih terlalu miskin dibandingkan pengertian sesungguhnya. Romo lebih cenderung menggunakan kata Wastu (Vasthuvidya : Jawa Kuna) yang mengacu kepada pemahaman hakikat, hal, perkara, kenyataan, norma, tolok ukur kesusilaan.

Tabel 1. Perbandingan Pengertian Arsitektur

\begin{tabular}{ll}
\hline Architectoon & Wastu \\
\hline Guna : tinjauan fungsional & Citra : tinjauan makna \\
Materi & Transenden \\
Estetika bentuk yang otonom, & Keselarasan dengan kosmos, \\
materialis dan bersifat & spiritual dan bersifat \\
informasi & transformasi \\
\hline
\end{tabular}

Sumber : Mangunwijaya, 1992

Menurut Romo Mangun, berarsitektur yang sesungguhnya harus meliputi guna dan citra:

- Mampu memberi makna dari materinya

- Berangkat dari eksistensi manusia : jasmani dan rohani yang bila dipisahkan akan mati

- Membahasakan dan mencerminkan jati diri pengguna. 
Beberapa kata kunci dari Wastucitra menyuratkan prinsip-prinsip maupun nilai yang mewarnai metode maupun hasil perancangan aristektur Romo Mangun, yaitu :

- Vernakularisme: arsitektur lokal nusantara merupakan pencerminan arsitektur yang menggabungkan guna dan citra

- Sikap arsitek untuk selalu memihak yang lemah

- Keindahan merupakan kebenaran, disaat yang tepat dan waktu yang tepat

\section{PROSES KREATIF}

Dalam proses menghasilkan sebuah karya, Romo Mangun cenderung menggunakan gambar makro sebagai pedoman awal. Desain selanjutnya merupakan respon terhadap perkembangan kondisi pelaksanaan proyek di lapangan. Kondisi ini diindikasikan dari:

- Kurang berperannya gambar perancangan pada tahap detail

- Waktu pelaksanaan proyek yang relatif lama

- Pembangunan yang dilakukan secara bertahap

- Seringnya perubahan desain dalam pelaksanaan

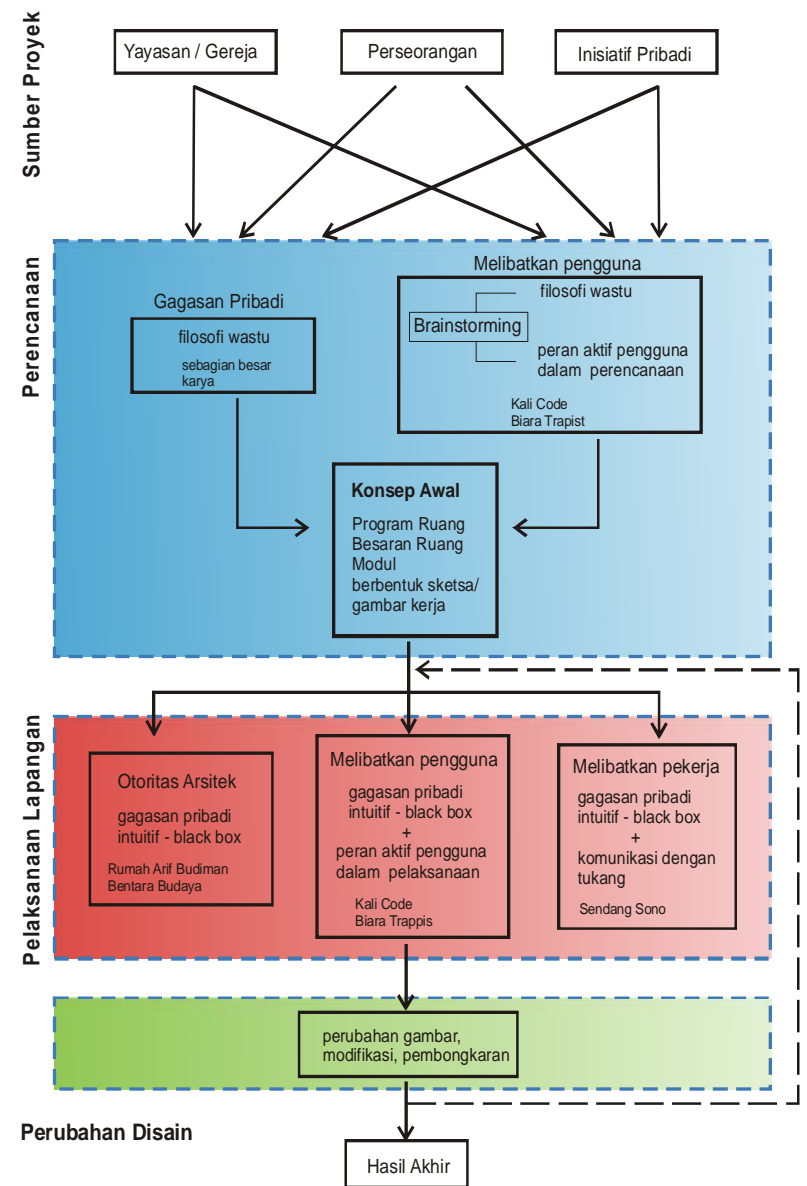

Sumber : analisa penulis, 2002

Diagram 1. Proses Desain YB Mangunwijaya

\section{TERBENTUKNYA KONSEP}

Pada tahap pembentukan konsep, Romo Mangun terlihat mempergunakan dua macam metode: pendekatan intuitif (bersifat black box) dan pendekatan rasional dan transparan. Metode rasional dan transparan sangat tampak pada Proyek Kali Code, Romo mengikutsertakan partisipasi aktif masyarakat pengguna sejak pembentukan konsep sampai hasil akhir.

Bentuk konsep Romo umumnya berupa sketsa dan gambar kerja, dengan dominasi gambar sketsa. Gambar paling lengkap dan satu-satunya yang bersifat teknis adalah rancangan Universitas Surabaya. Gambar kerja umumnya dikerjakan di kertas milimeter blok, didominasi oleh gambar dua dimensi dan sketsa detail.

Besaran ruang, program ruang ataupun modul yang secara konsisten diterapkan Romo Mangun tidak diungkapkannya secara eksplisit. Pendekatan konteks jauh lebih dominan dibanding pendekatan manerism. Keragaman bangunan dengan klien berbeda-beda yang dihasilkan Romo Mangun mungkin sebagai jawabnya. Akan tetapi secara garis besar dapat ditarik benang merah dari keseluruhan rancangan beliau. Untuk bangunan religius beliau menerapkan konsep kesatuan antara kesakralan ibadah dengan kehidupan manusia sehari-hari, perancangan menitikberatkan pada kesinambungan ruang luar dan ruang dalam gereja dengan tujuan menghindari kesan selama ini bahwa gereja adalah sesuatu yang suci, sakral dan najis disentuh oleh manusia yang berdosa. Untuk beberapa proyek Romo menerapkan sistem modul dalam menentukan besaran ruang, adapun program ruangnya lebih diserahkan pada penggunanya untuk menentukan sendiri kebutuhannya. (Kali Code, Sendang Sono dan Rumah Arif Budiman).
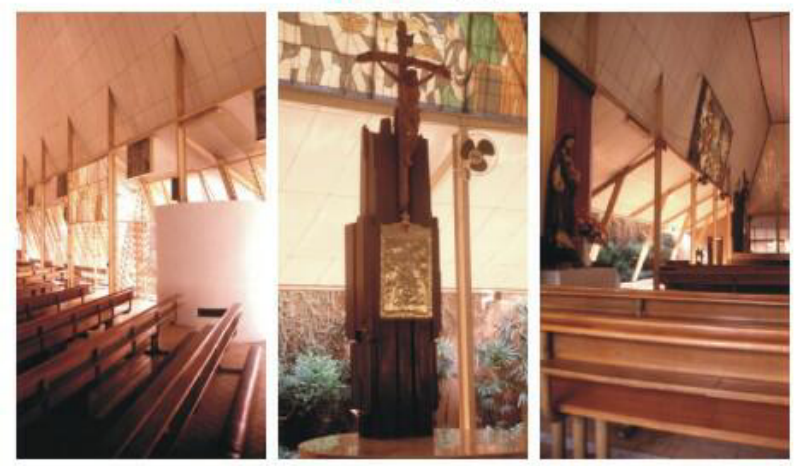

Sumber: www. mangunwijaya.or.id \& Diskusi Sehari Pemikiran dan Hasil Karya YB. Mangunwijaya, UAJY, 1992

Gambar 1. Gereja Salib Suci Cilincing, 1983-1984, konsep gereja yang menyatu dengan umat 


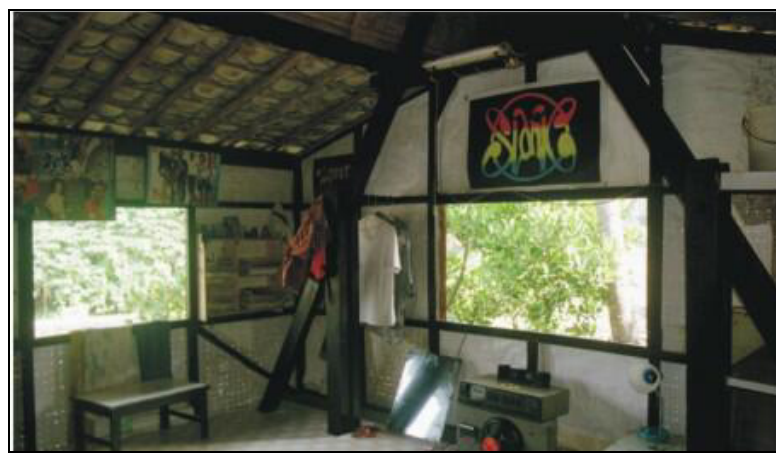

(a)

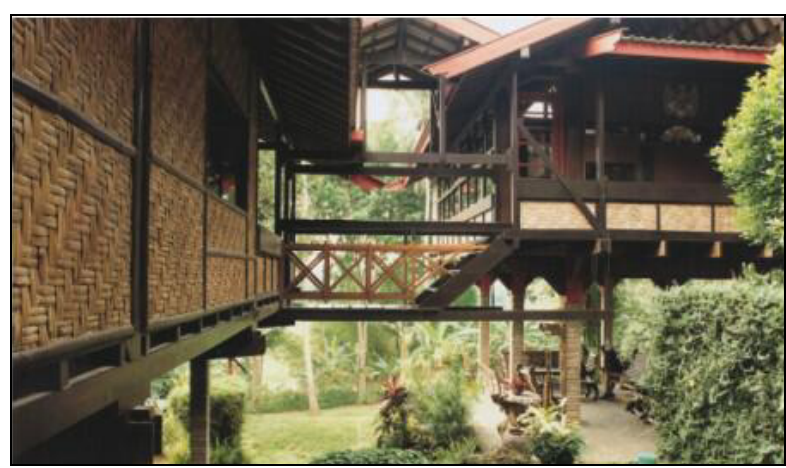

(b)

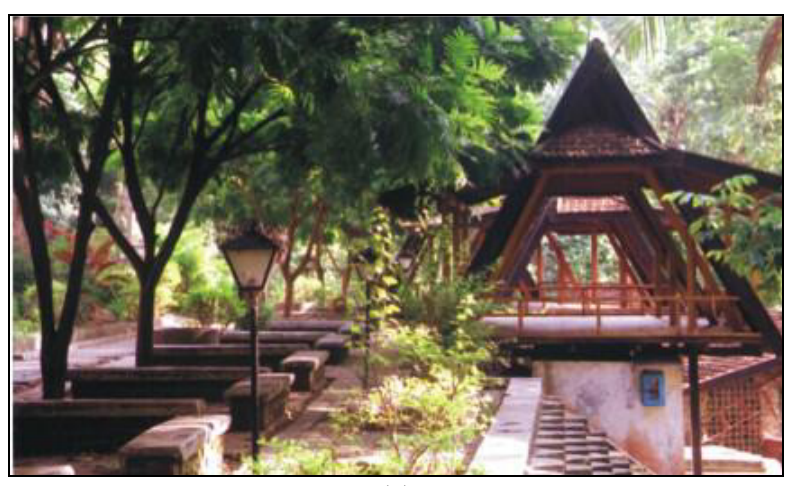

(c)

Gambar 2. (a). Pemukiman Tepi Kali Code, 19831987 konsep penataan kawasan kota, perancangan dengan metode partisipatif; (b). Rumah Tinggal Arif Budiman, 1986-1987; (c) Tempat Ziarah Sendangsono, 1972-1991

\section{TAHAP PELAKSANAAN}

Kemudian pada tahap pelaksanaan, umumnya memakan waktu yang lama karena beberapa faktor ${ }^{1}$ :

1. Kesibukan Romo di banyak tempat sedangkan semua proses pengerjaan hingga detail harus dengan persetujuan Romo

2. Kecenderungan untuk bemain detail rancangan

3. Seringnya perubahan rencana (pembongkaran dan penambahan)

\footnotetext{
${ }^{1}$ Analisa penulis dari studi literatur dan wawancara
}

Sebagai perancang Romo lebih banyak melakukan proses desain di lapangan pada saat proyek tengah dikerjakan. Perubahan sangat sering terjadi, seringkali satu bagian yang sudah selesai dikerjakan harus dibongkar untuk mengikuti perubahan. Perubahan rencana umumnya langsung dilakukan di lapangan dengan memberi instruksi detail pada tukang, dalam bentuk coretan-coretan, bahkan coretan di tanah. Alasan yang disampaikan Romo mengenai seringnya perubahan dalam desainnya adalah, "dunia ini berubah dengan sangat cepat”. ${ }^{2}$

\section{Hubungan dengan Klien}

Ditinjau dari sumber proyek sebagian besar merupakan tugas dari gereja, yayasan (bangunan religius, tempat ziarah, tempat retreat), berangkat dari pemikiran sendiri karena sesuai filosofi keberpihakan arsitek pada kaum lemah (Kali Code dan Proyek Air Bersih Gunung Kidul). Beberapa lagi didapatkan dari personal maupun instansi seperti Bentara Budaya Jakarta, Rumah Arif Budiman Salatiga. Adapun hubungan arsitek-klien sangat berperan dalam membentuk metode perancangan Romo Mangun :

- Pada sebagian besar proyek terutama proyek terutama dari gereja dan yayasan yang telah mempercayakan penuh hasil akhirnya pada Romo Mangun, Romo Mangun menggunakan metode intuitif dalam perancangan

- Proyek Bentara Budaya: Romo mengadakan perjanjian sebelumnya dengan pihak pemberi proyek agar tidak mengintervensi proses pembangunan, baik dari perencanaan hingga pelaksanaan. Mirip dengan sebelumnya, metode intuitif yang dipergunakan.

- Proyek Rumah Tinggal Arif Budiman, ada kontribusi klien memberi masukan program ruang, akan tetapi ternyata tidak terwujud di hasil akhir. Produk akhir hanya berupa massa bangunan, pembagian fungsi ruangnya diserahkan pada pemilik.

- Proyek Kali Code dan Biara Trapist : Walaupun berbeda konsep dalam perancangan maupun pelaksanaan di lapangan kedua proyek ini memiliki kemiripan. Kontribusi pengguna benarbenar dilibatkan dalam perancangan (terutama Proyek Kali Code) dan pelaksanaan. 

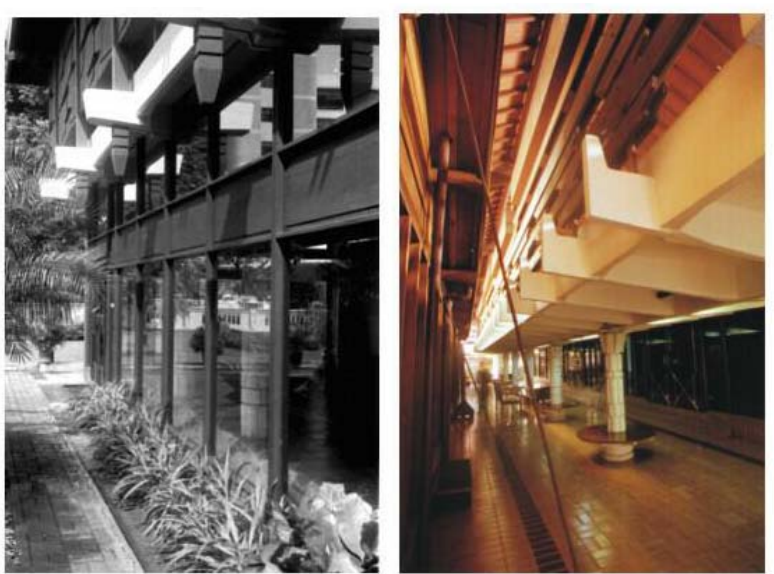

Gambar 3. Bentara Budaya, 1983-1984, konsep pembangunan dengan metode otonomi arsitek

\section{Hubungan dengan Pekerja dan Sikap Terhadap} Kondisi Tapak

Komunikasi perancang dengan dengan pelaksana (dalam hal ini mengacu pada tukang) langsung di lapangan sangat berpengaruh membentuk hasil akhir rancangan. Contoh paling terlihat adalah Proyek Komplek Ziarah Sendangsono, dilaksanakan tanpa gambar rencana, proyek ini mengandalkan komunikasi dengan pekerja dan respon langsung terhadap perkembangan tahap-tahap pembangunan.

Respon yang ada seringkali berasal dari permasalahan mensikapi kondisi tapak. Masih dengan contoh Komplek Ziarah Sendangsono, kondisi tapak di tepi sungai dengan tebing rawan longsor disikapi dengan dinding penahan yang berfungsi sekaligus sebagai tempat duduk. Vegetasi yang ada tetap dipertahankan tanpa ada penebangan dengan pertimbangan untuk mendapatkan kombinasi yang optimal dari pemanfaatan lingkungan alami, dan akomodasi kegiatan dan pembentukan suasana hening.
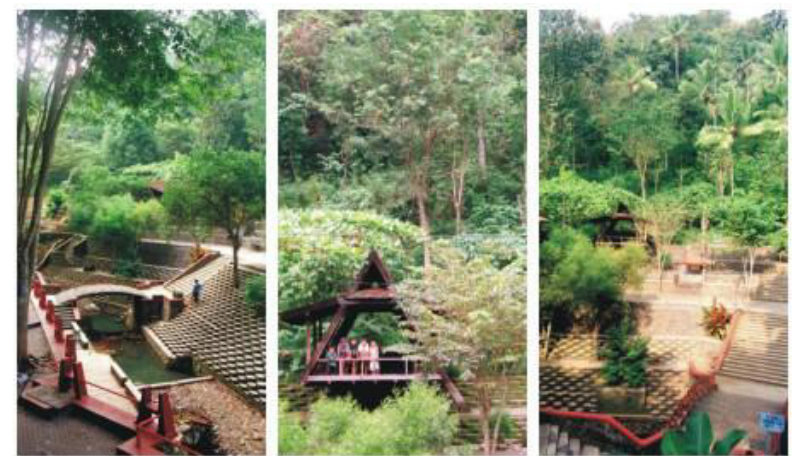

Gambar 4. Tempat Ziarah Sendangsono, 19721991 konsep pemanfaatan lingkungan, suasana dan kegiatan

\section{KESIMPULAN}

Dalam memahami metode perancangan Romo Mangun, tidak dapat dilepaskan dari pemahaman tentang filosofi beliau sendiri tentang arsitektur. Filosofi guna dan citra menjadi faktor dominan yang mempengaruhi tidak saja metode merancang tapi juga metode membangun beliau.

Metode perancangan Romo Mangun tidak dapat dipisahkan dengan metode membangun beliau, justru ide desain sebagian besar tercipta pada saat tahap pelaksanaan pembangunan. Sebagai konsekuensi adalah proses pembangunan yang bertahap dan memakan waktu relatif lama.

Metode perancangan karya yang satu dengan yang lain seringkali tidak sama, bandingkan Bentara Budaya yang cenderung didominasi oleh si arsitek dengan Kali Code yang cenderung patisipatif. Pendekatan yang dilakukan Romo Mangun, bukan saja dalam konsep atau gagasannya tapi sampai ke metode perancangannya sangat didominasi pandangan konteks, untuk pengguna, waktu dan tempat yang berbeda menuntut metode yang berbeda pula.

\section{DAFTAR PUSTAKA}

Diskusi Sehari, 1992, Pemikiran dan Hasil Karya YB Mangunwijaya, Fakultas Teknik Universitas Atmajaya Yogyakarta, Yogyakarta.

Mangunwijaya, YB, 1983, Sastra dan Religiositas.

Mangunwijaya, YB, Wastu Citra, 1988, Pengantar ke Ilmu Budaya Bentuk Arsitektur Sendi-sendi Filsafatnya Beserta Contoh-contoh Praktis, PT Gramedia Pustaka Utama, Jakarta.

Mangunwijaya, YB, 1993, Teknologi dan Dampak Kebudayaannya, vol 1, Yayasan Obor Indonesia, Jakarta.

http://www. mangunwijaya.or.id., 2000.

\section{LAMPIRAN:}

\section{Karya Arsitektur YB Mangunwijaya}

1. Gereja St. Maria Fatima, Sragen (1967-1968)

2. Gereja Maria Assumpta, Klaten (1968-1969)

3. Gereja St. Yusuf Jurukarya, Gondangwinangun, Klaten (1969-1970)

4. Gereja Santo Petrus, Borobudur, Magelang (1970)

5. Gereja St. Yusuf, Desa Bogo, Kalibawang (1970-1971)

6. Gereja San Inigo, Dirjodipuran, Solo - sudah dibongkar 
7. Wisma dan Gereja St. Theresia, Salam (1971)

8. Gereja St. Lukas, Desa Tambran, Bantul, Selatan Yogyakarta (1970-1971)

9. Wisma Unio dan Gereja Jetis, Yogyakarta

10. Rumah Tahanan Politik di Pulau Buru, (belum disurvey)

11. Perancangan Koridor Urban Malioboro, Yogyakarta

12. Wisma Sang Penebus, Nandan, Yogyakarta (1978)

13. Biara Redemptori's, Waikabubak, Sumba Barat (belum disurvey)

14. Seminari Anging Mammiri, Kaliurang, Yogyakarta (1977-1978)

15. Bentara Budaya, Jakarta (1984)

16. Peziarahan Sendang Sono, Sendang Sono (1972-1991)

17. Gereja Salib Suci, Cilincing, Jakarta (1983)

18. Pemukiman Tepi Kali Code, Gondolayu, Yogyakarta (1983-1987)

19. Rumah Arief Budiman, Salatiga (1987)

20. Universitas Surabaya, Surabaya

21. Makolwihan II, (tdk dibangun)

22. Gereja Maria Diangkat ke Surga, Malang

23. Wisma Kuwera, Mrican, Yogyakarta, 19861999

24. Penataan Lingkungan di Pantai Grigak, Desa di Gunung Kidul, 40 km Selatan Yogyakarta (1987-1989)

25. Pertapaan Trapistin Bunda Pemersatu, Gedono, Salatiga (Tahap I: 1984-1988 dan Tahap II: 1988-1991)

26. Bangunan Penampungan Korban Gempa, Maumere, Flores, 1993 (belum disurvey)

27. Rumah, Perahu, \& Perpustakaan Terapung, Kedungombo, Boyolali (1989-1994)

28. SD Kanisius dan Wisma Arita, Desa Mangunan, Kalasan (1993)

29. Kapel Bunda Maria Sapta Duka, Desa Mendut, Mungkid, Magelang (1993-1994)

30. Katedral Ambon, Ambon (tidak dibangun)

31. Seminarium Fermentum, Citepus, Bandung (1996)

32. Panti Mlati, Sleman, 1998 (desain belum selesai)

33. Jurusan Arsitektur UGM lama

34. Relief Eksterior Masjid Salahuddin, Bulaksumur, Yogya

35. Rumah Tinggal, Yogya

36. Bodi Mobil, Wonosari

37. Asrama Mahasiswa, Yogya

38. Rumah Parakitri T. Simbolon,

39. Relief Interior Gereja Sangkal Putung, Klaten

40. Katedral Dili (tdk dibangun)

41. Perpustakaan Pusat UGM (bentuk massa)
42. Rumah Senja Kardinal Justinus Darmoyuwono (belum sempat dibangun)

43. Relief dinding altar, meja altar, mimbar di Panti Semedi, Sangkal Putung, Klaten

44. Relief dinding altar dan meja altar di Gereja Muntilan

45. Gereja Mandongan di Srumbung.

46. Masjid di Roma (lomba) - gambar masih dicari

\section{Biografi YB Mangunwijaya}

1929 Lahir di Ambarawa

1959 Menerima tahbisan imamat, menjadi Imam Pradja di Keuskupan Agung Semarang. Tercatat sebagai Mahasiswa Jurusan Arsitektur ITB angkatan 1959

1966 Menyelesaikan studi di bidang arsitektur di West Fallische Technische Hochschule, Sekolah Tinggi Rhein, Westfallen-Aachen, Jerman.

1978 Mengikuti pendidikan di Fellow of Aspen Institute for Humanistic Studies di Aspen, Colorado, Amerika Serikat.

1966 Menyelesaikan studi di bidang arsitektur di West Fallische Technische Hochschule, Sekolah Tinggi Rhein, Westfallen-Aachen, Jerman.

1982 Pensiun dari profesi sebagai staf pengahar di Jurusan Arsitektur UGM Yogyakarta

1988 Menerbitkan buku Wastucitra mengenai gagasan dan filosofinya tentang arsitektur sekaligus menandai perpisahannya dengan dunia 'Grand Architecture'

1998 Mengundurkan diri diri dari dunia arsitektur

1999 Wafat dan dimakamkan di Yogyakarta.

\section{Penghargaan YB Mangunwijaya}

1991 IAI Award for Architecture untuk Kategori Penghargaan Khusus: Tempat Ziarah Sendangsono, Kulon Progo, DI Yogyakarta.

Nominasi untuk Kategori Rumah Tinggal : Biara Trapist Bunda Pemersatu, Gedono, Salatiga, Jawa Tengah dan Rumah Tinggal Arif Budiman, Salatiga, Jawa Tengah.

1992 Aga Khan Award for Architecture: Pemukiman Kali Code, Terban, Yogyakarta, di Yogyakarta 